\title{
Investigation on flavonoid composition and anti free radical potential of Sida cordata
}

\author{
Naseer Ali Shah ${ }^{1 \dagger}$, Muhammad Rashid Khan ${ }^{1 *}$, Bushra Ahmad ${ }^{1 \dagger}$, Farah Noureen ${ }^{1 \dagger}$, Umbreen Rashid ${ }^{1 \dagger}$ \\ and Rahmat Ali Khan ${ }^{2+}$
}

\begin{abstract}
Background: Sida cordata, a member of Family Malvaceae is used in folk medicine for various ailments including liver diseases. In this study we investigated, its flavonoid constituents, in vitro antioxidant potential against different free radicals and hepatoprotection against carbon tetrachloride $\left(\mathrm{CCl}_{4}\right)$-induced liver damage in rat.

Methods: Dried powder of S. cordata whole plant was extracted with methanol and the resultant (SCME) obtained was fractionated with escalating polarity to obtain $n$-hexane fraction (SCHE), ethyl acetate fraction (SCEE), n-butanol fraction (SCBE) and the remaining soluble portion as aqueous fraction (SCAE). Diverse in vitro antioxidants assays such as DPPH, $\mathrm{H}_{2} \mathrm{O}_{2}, \cdot \mathrm{OH}, \mathrm{ABTS}, \beta$-carotene bleaching assay, superoxide radical, lipid peroxidation, reducing power, and total antioxidant capacity were studied to assess scavenging potential of methanol extract and its derived fractions. On account of marked scavenging activity SCEE was selected to investigate the hepatoprotective potential against $\mathrm{CCl}_{4}$ induced toxicity in Sprague-Dawley male rats by assessing the level of serum markers (alkaline phosphatase, alanine transaminase, aspartate transaminase, lactate dehydrogenase, bilirubin, and Y-glutamyltransferase) and of liver antioxidant enzymes such as catalase (CAT), superoxide dismutase (SOD), peroxidase (POD), glutathione-S-transfers (GST), glutathione reductase (GSR), glutathione peroxidase (GSH-Px), and reduced glutathione (GSH) and lipid peroxidation (TBARS). Histology of the liver was performed to study alteration in histoarchitecture. Existence of active flavonoids was established by thin layer chromatographic studies.

Results: Considerable amount of flavonoid and phenolic contents were recorded in the methanol extract and its derived fractions. Although the extract and all its derived fractions exhibited good antioxidant activities however, the most distinguished scavenging potential was observed for SCEE. Treatment of SCEE decreased the elevated level of serum marker enzymes induced with $\mathrm{CCl}_{4}$ administration whereas increased the activity of hepatic antioxidant enzymes (CAT, SOD, POD, GST, GSR and GSH-Px). Hepatic concentration of GSH was increased while lipid peroxidation was decreased with SCEE administration in $\mathrm{CCl}_{4}$ intoxicated rats. Presence of apigenin with some unknown compounds was observed in SCEE by using thin layer chromatography.
\end{abstract}

Conclusions: These results revealed the presence of some bioactive compound in the ethyl acetate fraction, confirming the utility of $\mathrm{S}$. cordata against liver diseases in folk medicine.

Keywords: Sida cordata, Phytochemistry, Antioxidant assays, $\mathrm{CCl}_{4}$, Liver toxicity

\footnotetext{
* Correspondence: mrkanqau@yahoo.com

${ }^{\dagger}$ Equal contributors

'Department of Biochemistry, Faculty of Biological Sciences, Quaid-i-Azam University, Islamabad 45320, Pakistan

Full list of author information is available at the end of the article
} 


\section{Background}

Free radicals are classified having an unpaired electron. They belong to extremely reactive species, generated continuously in cells either as by-products of metabolism or by leakage from mitochondrial respiration [1]. In the previous decade, there has been a mounting interest in the medical implications of free radicals. Free radicals such as superoxide radical $\left(\mathrm{O}_{2}^{-}\right)$, hydroxyl radical $(\cdot \mathrm{OH})$, hydrogen peroxide $\left(\mathrm{H}_{2} \mathrm{O}_{2}\right)$ and lipid peroxides $(\mathrm{LOOH})$ are becoming of enormous concern in human diseases. They are recognized for DNA damage, lipid peroxidation and protein breakdown along with role in the pathogenesis of many clinical disorders such as inflammatory diseases, cardiac diseases, asthma, Alzheimer's, Parkinson's and aging $[2,3]$. Radicals such as $\mathrm{O}_{2}^{-}, \cdot \mathrm{OH}$, and $\mathrm{H}_{2} \mathrm{O}_{2}$ etc. arbitrate components of the inflammatory response, with production of cyclic nucleotides, migratory factors and eicosanoids. Superoxide radicals intensify the inflammatory process by adhesion of polymorphonuclear leukocytes to the endothelium, increasing vascular permeability and stimulation of platelet aggregation [4]. Free radicals and reactive oxygen species are also the major cause of introducing genetic mutation leading to different sorts of cancer. Evidence is growing for a role of dietary phytochemicals, including ascorbic acid, flavonoids, carotenoids and tocopherol as an antioxidants in the maintenance of health and resistance to diseases [5].

Natural products such as flavonoids and phenolics have been observed to be efficient free radical scavengers and lipid peroxidation inhibitors [6,7]. Several synthetic based antioxidant compounds have proved to be toxic and/or mutation inducer, resulting in attention of many researchers to quest for natural antioxidants.

S. cordata, member of the Malvaceae Family, is a trailing way side herb found frequently growing in shady places. It is cosmopolitan in Pakistan, India and other tropical countries and is mostly distributed in clearing in the forest and as weeds in the overgrown grass of gardens and public parks [8]. It is known as Farid buti, Rajbala, Bhumibala and Shaktibala in India [9] and Simak in Pakistan [10]. It is extensively used for therapeutic purposes in the codified Indian systems of medicine namely Siddha and Ayurveda. Its roots are used as diuretic, astringent, stomachic, febrifuge and demulcent and seeds are applied as laxative, aphrodisiac and demulcent; recommended in cystitis, colic gonorrhea, tenseness, and piles [10]. It has a potential for strengthening and glowing of the body [9]. In folk medicine, female uses it as soup in the last days of pregnancy to reduce pain of labor and reducing the period. It also leads to decrease the period of post parturition bleeding [11]. The abortifacient effect of alcoholic extract is also reported in pregnant rats [8].

The whole plant material is used for chronic hepatic diseases [12]. Its hepatoprotective effects have been investigated in an in vitro study [13]. Mistry et al. [14] reported that crude ethanol extract of the leaves of $S$. cordata is hepatoprotective against $\mathrm{CCl}_{4}$ induced toxicity in rat. However, a systematic approach is required to determine the main fraction involved in the antioxidant potential of this plant. The present study was under taken to evaluate the methanol extract and its derived fractions through various in vitro anti free radical assays with subsequent use of the desired fraction to investigate its antioxidant capacity against $\mathrm{CCl}_{4}$ induced hepatic toxicity in animal model. Methanol extract and all its derived fractions were additionally subjected to the total flavonoid content, total phenolic content and to establish the existence of various active flavonoid constituents by thin layer chromatography.

\section{Methods}

Plant collection and preparation of extract

The whole plant was collected from the campus of Quaidi-Azam University, Islamabad, Pakistan and recognized by their local names and then confirmed by Prof. Dr. Mir Ajab Khan, Department of Plant Sciences, Quaid-i-Azam University, Islamabad and Dr. Muhammad Zafar, Curator, Herbarium, Quaid-i-Azam University, Islamabad. Voucher specimen with accession No. 27824 was deposited at the Herbarium, Quaid-i-Azam University, Islamabad.

Shade dried $4 \mathrm{~kg}$ powder of $S$. cordata whole plant was extracted twice for $72 \mathrm{~h}$ in $8 \mathrm{~L}$ of methanol and filtered through Whatmann filter paper \# 45, and the filtrate was concentrated through rotary vacuum evaporator at reduced pressure to get methanol extract (SCME). To sort the extract in increasing order of polarity it was suspended in distilled water $(6 \mathrm{~g} / 250 \mathrm{ml})$ and passed through different solvents $(250 \mathrm{ml}$ each) in the order of n-hexane $(\mathrm{SCHE}) \rightarrow$ ethyl acetate (SCEE) $\rightarrow$ n-butanol (SCBE) to get different fractions by using separating funnel. The soluble residue was termed aqueous fraction (SCAE). All the fractions were stored at $4^{\circ} \mathrm{C}$ until further use.

\section{Phytochemical analysis \\ Total phenolic content}

Spectrophotometric method [15] was used for determination of total phenolic content. In short, $1 \mathrm{ml}$ of the extract and its derived fractions $(1 \mathrm{mg} / \mathrm{ml})$ were mixed with $1 \mathrm{ml}$ of Folin-Ciocalteu's reagent followed by $\mathrm{Na}_{2} \mathrm{CO}_{3}$ (7\%, $\left.10 \mathrm{ml}\right)$ after $5 \mathrm{~min}$. Mixture was thoroughly mixed with $13 \mathrm{ml}$ of deionized distilled water and incubated at $23^{\circ} \mathrm{C}$ in the dark. After $90 \mathrm{~min}$, absorbance was recorded at $750 \mathrm{~nm}$. Total phenolic content was calculated from calibration curve of gallic acid serial dilutions. Estimation of phenolic compounds was recorded in triplicate and expressed as $\mathrm{mg}$ of gallic acid equivalents (GAE) per $g$ of dried extract. 


\section{Total flavonoid content}

In test tubes, samples $(0.3 \mathrm{ml})$ of $S$. cordata were thoroughly mixed with $30 \%$ methanol, $0.5 \mathrm{M} \mathrm{NaNO}_{2}$ $(0.15 \mathrm{ml})$ and $0.3 \mathrm{M} \mathrm{AlCl} 3.6 \mathrm{H}_{2} \mathrm{O}(0.15 \mathrm{ml})$ followed by addition of $1 \mathrm{ml} \mathrm{NaOH}$ (IM) after $5 \mathrm{~min}$. Absorbance was measured at $506 \mathrm{~nm}$ against the reagent blank. Total flavonoid content was estimated by using a calibration curve of rutin and expressed as mg rutin equivalents per $\mathrm{g}$ of dried extract [16].

\section{Thin layer chromatography}

Extract and all fractions of S. cordata were dissolved (60 $\mathrm{mg} / \mathrm{ml}$ ) separately in HPLC grade methanol [17]. Silica gel TLC plates were cut into $20 \times 20 \mathrm{~cm}$ sections. Each section was marked at $1 \mathrm{~cm}$ from one side. A volume of $10 \mu \mathrm{l}$ of each sample and standard compounds such as myricetin, rutin, apigenin, kaempherol, catechin, quercetin, tannic acid, ascorbic acid, salicylic acid and caffeic acid were spotted by using a capillary tube on the line marked at one corner of the plate. Plates were allowed to develop after $20 \mathrm{~min}$ of vapor saturation in $120 \mathrm{ml}$ of mobile phase; $n$-butanol, acetic acid and water (4:1:5). Plates were moved out when the mobile phase reached 1 $\mathrm{cm}$ below at the upper end. Solvent front was marked with lead pencil, air dried. The plates were dipped in a solution of $1 \%$ ethanolic 2-aminoethyle diphenyl borinate followed by a $5 \%$ ethanolic solution of polyethylene glycol-400. Phenolics and flavonoids were identified through its attributed colors under UV at 365 and $255 \mathrm{~nm}$. RF values were calculated as:

$$
\begin{aligned}
\mathrm{RF}= & \text { Distance covered by spot } / \text { Distance covered } \\
& \text { by mobile phase }
\end{aligned}
$$

\section{Antioxidant assays \\ Samples preparation}

S. cordata extract, fractions and positive standards (ascorbic acid, butylated hydroxytoluene, catechin and gallic acid) $200 \mu \mathrm{g}$ were dissolved in $1 \mathrm{ml}$ analytical methanol. These solutions were further serially diluted to $100 \mu \mathrm{g} / \mathrm{ml}$ and $50 \mu \mathrm{g} / \mathrm{ml}$. In all the different antioxidant assays, same dilutions of sample and standards were used; while standard altered as per assay requirement.

\section{DPPH radical scavenging assay}

The DPPH (1, 1-diphenyl-2-picryl-hydrazyl) assay was performed according to the protocol of Sirajuddin et al. [18]. DPPH (24 mg) was dissolved in $100 \mathrm{ml}$ methanol (stock solution). The solution was stored at $20^{\circ} \mathrm{C}$ until required. A working solution was made by diluting DPPH stock solution by methanol until the absorbance of $0.98 \pm 0.02$ was obtained at $517 \mathrm{~nm}$. Working DPPH solution $(0.9 \mathrm{ml})$ was added to $100 \mu \mathrm{l}$ of various concentrations of test samples and incubated for $60 \mathrm{~min}$ in the dark at room temperature after being shaken well. Subsequently, the absorbance of the test samples was recorded at $517 \mathrm{~nm}$. Ascorbic acid was used as standard.

Scavenging activity was calculated using the following equation

$$
\begin{aligned}
& \text { DPPH radical Scavering effect }(\%) \\
& \quad=[(\text { control-sample }) /(\text { control })] \times 100
\end{aligned}
$$

\section{Hydrogen peroxide scavenging assay}

The method of Bokhari et al. [19] was followed to investigate hydrogen peroxide scavenging capacity of samples. Hydrogen peroxide $(2 \mathrm{mM})$ solution was prepared in phosphate buffer $(50 \mathrm{mM}, \mathrm{pH}$ 7.4). Samples $(100 \mu \mathrm{l})$ were pipetted into eppendorfs and their volume made up to $400 \mu \mathrm{l}$ with $50 \mathrm{mM}$ phosphate buffer (pH 7.4). $\mathrm{H}_{2} \mathrm{O}_{2}$ solution $(600 \mu \mathrm{l})$ was added and absorbance at $230 \mathrm{~nm}$ was taken 10 min after vortexing the eppendorfs. Percent scavenging activity was determined by following formula;

$$
\begin{aligned}
& \mathrm{H}_{2} \mathrm{O}_{2} \% \text { scavenging activity } \\
& =(1 \text {-absorbance of sample/absorbance of control }) \times 100
\end{aligned}
$$

Ascorbic acid served as standard.

\section{Hydroxyl radical scavenging assay}

The antioxidant activity was evaluated by method reported by Halliwell and Gutteridge [20]. The reaction mixture comprised of 2-deoxyribose $(2.8 \mathrm{mM}, 500 \mu \mathrm{l})$ in $50 \mathrm{mM}$ of phosphate buffer, $100 \mu \mathrm{l}$ of $0.2 \mathrm{M}$ hydrogen peroxide solution, $200 \mu \mathrm{l}$ of $0.1 \mathrm{M}$ ferric chloride, $0.1 \mathrm{M}$ EDTA and $100 \mu \mathrm{l}$ of test sample. The reaction was initiated by the addition of $100 \mu \mathrm{l}$ of ascorbate $(0.3 \mathrm{M})$. The mixture was incubated at $37^{\circ} \mathrm{C}$ for $60 \mathrm{~min}$. TCA $(2.8 \%$ $\mathrm{w} / \mathrm{v}, 1 \mathrm{ml}$ ) and $1 \mathrm{ml}$ of thiobarbituric acid (TBA) solution in $50 \mathrm{mM}$ of sodium hydroxide $(1 \% ; \mathrm{w} / \mathrm{v})$ was added. This reaction mixture was heated for $15 \mathrm{~min}$ in boiling water bath and then allowed to cool. Absorbance was recorded at $532 \mathrm{~nm}$.

$$
\begin{aligned}
& \text { Hydroxyl scavenging activity }(\%) \\
& \quad=1 \text {-(Asorbance of sample/Absorbance of control } \times 100)
\end{aligned}
$$

\section{ABTS radical cation scavenging activity}

Re et al. [21] methodology with slight modification was followed for ABTS (2, 2 azobis, 3-ethylbenzothiozoline-6sulphonic acid) radical cation scavenging activity. ABTS (7 $\mathrm{mM}$ ) solution was reacted with $2.45 \mathrm{mM}$ potassium persulfate and kept overnight in dark for generation of dark colored ABTS radicals. For the assay, the solution was diluted with $50 \%$ ethanol for an initial absorbance of 0.7 at $745 \mathrm{~nm}$. Activity was determined by adding $100 \mu \mathrm{l}$ 
sample of different dilution with $1 \mathrm{ml}$ of ABTS solution in glass cuvette. Decrease in absorbance was measured after one min and 6 min of mixing. The difference was calculated and compared with control. Percent inhibition was calculated by following formula;

$$
\begin{aligned}
& \text { ABTS scavenging effect }(\%) \\
& =[(\text { control absorbance-sample absorbance }) / \\
& \quad(\text { control absorbance })] \times 100
\end{aligned}
$$

\section{Anti lipid peroxidation assay}

This assay was performed as illustrated by Dorman et al. [22]. An aliquot of egg yolk $(10 \%, w / v)$ was prepared in $\mathrm{KCl}(1.15 \%, \mathrm{w} / \mathrm{v})$. The yolk was homogenized for $30 \mathrm{sec}$ and subsequently subjected to ultrasonication for $5 \mathrm{~min}$. Each sample $(100 \mu \mathrm{l})$ at varying concentrations (200, $100,50 \mu \mathrm{g} / \mathrm{ml}$ in methanol) and $500 \mu \mathrm{l}$ of yolk homogenate were pipetted into eppendorfs and volume was made up to $1 \mathrm{ml}$ with distilled water. It was mixed with $1.5 \mathrm{ml}$ of acetic acid (20\%, pH 3.5$)$ and TBA $(0.8 \%, \mathrm{w} / \mathrm{v})$ in sodium dodecyl sulphate $(1.1 \%, \mathrm{w} / \mathrm{v})$. The reaction mixture was vortexed and incubated for $60 \mathrm{~min}$ in water bath. $n$ Butanol was added after cooling at room temperature, stirred and then centrifuged for $10 \mathrm{~min}$ at $3000 \mathrm{rpm}$. Butylated hydroxytoluene served as standard. The absorbance at $532 \mathrm{~nm}$ of supernatant was recorded.

The percent anti lipid peroxidation was determined by formula $(1-\mathrm{S} / \mathrm{C}) \times 100$

Where

$\mathrm{C}=$ Absorbance of control and $\mathrm{S}=$ Absorbance of test sample

\section{$\beta$-Carotene bleaching assay}

Elzaawely et al. [23] modified method was used for $\beta$ carotene bleaching assay. $\beta$-carotene $(2 \mathrm{mg}$ ) was dissolved in $10 \mathrm{ml}$ of chloroform and blended with $20 \mathrm{mg}$ of linoleic acid and $200 \mathrm{mg}$ of Tween 80 followed by removal of chloroform under nitrogen with subsequent addition of $50 \mathrm{ml}$ of distilled water with vigorous shacking to prepare $\beta$-carotene linoleate emulsion. An aliquot of each sample $(50 \mu \mathrm{l})$ was mixed with $1 \mathrm{ml}$ of the emulsion, vortexed and absorbance was determined at $470 \mathrm{~nm}$ immediately against the blank solution. Capped tube was then kept in a water bath at $45^{\circ} \mathrm{C}$ for $2 \mathrm{~h}$ and the difference between the initial readings is calculated by measuring the reading after $2 \mathrm{~h}$. $\beta$-Carotene bleaching inhibition was estimated by the following equation:

$$
\text { Bleaching inhibition }(\%)=\left(\mathrm{A}_{0 \mathrm{t}}-\mathrm{A}_{120 \mathrm{t}} / \mathrm{A}_{0 \mathrm{C}}-\mathrm{A}_{120 \mathrm{C}}\right) \times 100
$$

\section{Superoxide anion radical scavenging assay}

Riboflavin light NBT system assay was followed for superoxide radical scavenging activity [24]. The reaction mixture contained $0.5 \mathrm{ml}$ of phosphate buffer $(50 \mathrm{mM}$, $\mathrm{pH}$ 7.6), $0.3 \mathrm{ml}$ riboflavin ( $50 \mathrm{mM}), 0.25 \mathrm{ml}$ PMS (20 $\mathrm{mM})$, and $0.1 \mathrm{ml} \mathrm{NBT}(0.5 \mathrm{mM})$, prior to the addition of $1 \mathrm{ml}$ sample in methanol. Florescent lamp was used for starting the reaction. Absorbance was recorded at 560 $\mathrm{nm}$ after incubation of $20 \mathrm{~min}$ under light. The percent inhibition of superoxide anion generation was calculated using the following formula:

$$
\begin{aligned}
& \text { Percent scavenging activity }(\%) \\
& \quad=(1 \text {-Absorbance of sample/Absorbance of control }) \times 100
\end{aligned}
$$

\section{Reducing power activity assay}

Reducing power of test samples was determined following modified protocol reported by Oyaizu [25]. A volume of $100 \mu \mathrm{l}$ of various concentrations $(50,100$ and $200 \mu \mathrm{g} / \mathrm{ml})$ of test samples, $100 \mu \mathrm{l}$ of phosphate buffer $(0.2 \mathrm{M}$, pH 6.6) and $100 \mu \mathrm{l}$ of potassium ferricyanide $(10 \mathrm{mg} / \mathrm{ml})$ were thoroughly mixed followed by incubation for $30 \mathrm{~min}$ at $50^{\circ} \mathrm{C}$. Trichloroacetic acid (1\%; $\left.0.25 \mathrm{ml}\right)$ was added to the mixture. A volume of $0.25 \mathrm{ml}$ of the mixture was mixed with distilled water $(0.25 \mathrm{ml})$ and $0.1 \%(\mathrm{w} / \mathrm{v})$ ferric chloride $(0.4 \mathrm{ml})$. The absorbance was recorded at $700 \mathrm{~nm}$ after $30 \mathrm{~min}$. Increased absorbance is indicative of high reducing power. Gallic acid was used as standard.

\section{Total antioxidant capacity (Phosphomolybdate assay)}

The total antioxidant potency of test compounds was investigated by phosphomolybdate method of Umamaheswari and Chatterjee [26]. An aliquot of $0.1 \mathrm{ml}$ of different concentrations $(50,100$ and $200 \mu \mathrm{g} / \mathrm{ml})$ of each sample was added to $1 \mathrm{ml}$ of reagent $\left(0.6 \mathrm{M} \mathrm{H}_{2} \mathrm{SO}_{4}, 0.028 \mathrm{M}\right.$ sodium phosphate , $0.004 \mathrm{M}$ ammonium molybdate) and incubated for $90 \mathrm{~min}$ at $95^{\circ} \mathrm{C}$ in a water bath. Absorbance was recorded at $765 \mathrm{~nm}$ after the samples cooled to room temperature. Ascorbic acid served as standard.

\section{Acute toxicity studies in rat}

For acute toxicity study, 42 male Sprague Dawley rats of good health were randomly divided into seven groups. Animals were off feed but have open access to water 15 h prior of test samples. Group I served as control group and received $15 \%$ DMSO in olive oil intraperitoneally. However, Group II, III, IV, V, VI, and VII received 500, 400, 300, 200, 100 and $50 \mathrm{mg} / \mathrm{kg}$ of SCEE respectively in DMSO. General behavior of animals was noted after 120 min of treatment. Food and water were given ad libitum. Animals were screened for mortality and morbidity for 15 days [27].

\section{Experimental design for in vivo study}

Male Sprague Dawley rats (180-200 g) of seven weeks old were used as animal model in this study. They were 
maintained in cages at room temperature of $25 \pm 3^{\circ} \mathrm{C}$ with a $12 \mathrm{~h}$ light/dark cycle and free access to water and feed. The study protocol was approved (No.0244) by the ethical committee of Quaid-i-Azam University, Islamabad, Pakistan for laboratory animal care and experimentation.

Patrick et al. [28] protocol with slight modification was followed to study the antioxidant potential of SCEE. Forty two male rats were randomly distributed into 7 groups (6 rats/group). Group I was remained untreated. Group II was treated with 15\% DMSO in olive oil $(1 \mathrm{ml} /$ $\mathrm{kg}$ b.w) and have free access to food materials. Animals of Group III, IV, V and VI received $1 \mathrm{ml} / \mathrm{kg}$ b.w of $\mathrm{CCl}_{4}$ (20\% in olive oil; v/v) intraperitoneally on alternative days for four weeks. Group III was treated with $\mathrm{CCl}_{4}$ only while group IV with $200 \mathrm{mg} / \mathrm{kg}$ b.w of silymarin in DMSO after $\mathrm{CCl}_{4}$ administration. Group V received 150 $\mathrm{mg} / \mathrm{kg}$ b.w of SCEE and group VI received $300 \mathrm{mg} / \mathrm{kg}$ b. $\mathrm{w}$ of SCEE intragastrically, in DMSO after $\mathrm{CCl}_{4}$ treatments. Animals of group VII were given only SCEE in DMSO at dose of $300 \mathrm{mg} / \mathrm{kg}$ b.w intragastrically. After $24 \mathrm{~h}$ of the last treatment, all the animals were dissected. Blood was collected from heart by $3 \mathrm{ml}$ syringe; the liver was removed and rinsed in ice-cold saline solution. Half liver was preserved in formaldehyde for histology and half was treated with liquid nitrogen and preserved at $-20^{\circ} \mathrm{C}$ for further analysis.

\section{Liver marker enzymes assessment in serum}

Liver marker enzymes in serum such as aspartate transaminase (AST), alanine transaminase (ALT), alkaline phosphatase (ALP), gamma glutamyltransferase $(\gamma-\mathrm{GT})$ and lactate dehydrogenase $(\mathrm{LDH})$ were analyzed by using standard AMP diagnostic kits (Stattogger Strasse 31b 8045 Graz, Austria).

\section{Assessment of antioxidant status}

For antioxidant status assessment of different groups, 70 mg of liver tissue was homogenized in 10 volumes of 100 mM KH2PO4 buffer containing 1 mM EDTA (pH 7.4) and centrifuged at $12,000 \times \mathrm{g}$ for $30 \mathrm{~min}$ at $4^{\circ} \mathrm{C}$. The supernatant was collected and used for determination of antioxidant enzymes and protein profile. The concentration of protein was estimated following the method of Lowry et al. [29] and antioxidant enzymes, including the activity of catalase (CAT), peroxidase assay (POD) [30], superoxide dismutase (SOD) [31], glutathione Stransferase assay (GST) [32], glutathione reductase (GSR) [33], glutathione peroxidase (GSHPx) [34], reduced glutathione assay (GSH) [35] and lipid per oxidation assay (TBARS) [36] were performed on hepatic samples.

\section{Liver histology}

For histology small pieces of liver tissue from each group were fixed for $3-4 \mathrm{~h}$ in fixative sera followed by dehydration with ascending grades of alcohol (80\%, 90\%, and $100 \%$ ) and transferred in cedar wood oil. When tissues become clear then all tissues were embedded in paraffin and prepared blocks for further microtomy. Thin sections 3-4 $\mu \mathrm{m}$ were prepared with microtome; wax was removed, stained with hemotoxylin-eosin and photographed under light microscope at $40 \times$.

\section{Statistical analysis}

All values are mean of triplicates. One way ANOVA analysis was carried by using Statistix 8.1 to assess the difference between various groups. The graph pad prism was used to calculate $\mathrm{IC}_{50}$ values. Correlation between $\mathrm{IC}_{50}$ values of different assays with total flavonoids and total phenolics was calculated by Pearson's correlation coefficient with a significance level of $\mathrm{P}<0.05$.

\section{Results and discussion}

\section{Extract and fraction yield}

$S$. cordata crude methanol extract gave a yield of 18 percent $(w / w)$, proceeded to further fractionation by using different organic solvents based on a difference of polarity index. Non polar $n$-hexane yield $35 \%$ fraction, while polar ethyl acetate, $n$-butanol yield $15 \%$ and $10 \%$ respectively. Residue soluble fraction known as aqueous fraction gave a yield of $40 \%$ (Figure 1). Mistry et al. [14] also reported extract yield in a similar range (17.6\%) but solvent with different polarity and plant part.

\section{Phytochemical analysis}

\section{Total phenolic content and total flavonoid content}

Flavonoids and phenolics are known to have good antioxidant capacity and it is likely that the antioxidant activity of extract/fraction might be due to these compounds. Therefore these are quantified to show its relation with antioxidant potential. Table 1 shows the quantity of total flavonoid and total phenolic content.

Maximum quantity of total flavonoid content was observed in SCEE (312 $\pm 1 \mathrm{mg}$ rutin equivalent /g dry extract) while the lowest in SCHE $(66 \pm 5.1 \mathrm{mg}$ rutin equivalent/g dry extract). $\mathrm{SCEE}>\mathrm{SCME}>\mathrm{SCBE}>$

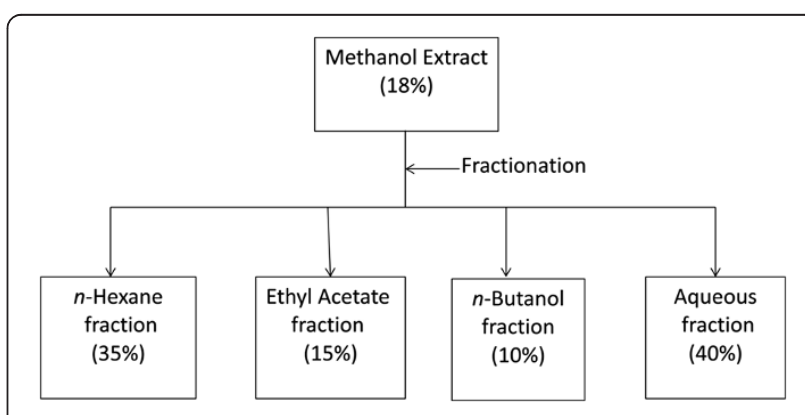

Figure 1 Flow sheet of extraction and fractionation of S. cordata with percent yield. 


$\begin{aligned} & \text { Table 1 Quantitative profile of total flavonoids content } \\
& \text { and total phenolic content in the methanol extract and } \\
& \text { various fractions of } \mathbf{S} \text {. cordata }\end{aligned}$
\begin{tabular}{lll} 
Extract/Fraction & $\begin{array}{l}\text { Total flavonoid content } \\
\text { (mg rutin equivalent/g } \\
\text { extract/fraction) }\end{array}$ & $\begin{array}{l}\text { Total phenolic content } \\
\text { (mg gallic acid } \\
\text { equivalent/g } \\
\text { extract/fraction) }\end{array}$ \\
\hline SCME & $154 \pm 6.7^{\mathrm{a}}$ & $286.7 \pm 17.5^{\mathrm{c}}$ \\
SCHE & $66 \pm 5.1^{\mathrm{e}}$ & $49.0 \pm 3.6^{\mathrm{d}}$ \\
SCEE & $312 \pm 1^{\mathrm{b}}$ & $683.3 \pm 15.3^{\mathrm{a}}$ \\
SCBE & $246 \pm 1^{\mathrm{c}}$ & $485.3 \pm 13.2^{\mathrm{b}}$ \\
SCAE & $88 \pm 5.6^{\mathrm{d}}$ & $24.6 \pm 2.7^{\mathrm{e}}$ \\
\hline
\end{tabular}

Each values represented in tables are means $\pm S D(N=3)$. Values with different superscripts within same column are significantly different $(P<0.05)$. ( $(\mathrm{CHE})$; $n$-hexane fraction, (SCEE); ethyl acetate fraction, (SCBE); $n$-butanol fraction, (SCAE), aqueous fraction.

SCAE > SCHE descending order of total flavonoid content was observed. Maximum total phenolic content was recorded in SCEE $(683.3 \pm 5.3 \mathrm{mg}$ gallic acid equivalent $/ \mathrm{g}$ dry extract) while the lowest quantity was observed in SCAE (24.6 $\pm 2.7 \mathrm{mg}$ gallic acid equivalent /g dry extract). Descending order of SCEE > SCBE > SCME > SCHE > SCAE was recorded for total phenolic content.

\section{Thin layer chromatography}

Thin layer chromatography (TLC) was performed by using 10 standards of flavonoids and phenolics. $S$. cordata methanol extract and all the derived fractions showed the presence of compounds by using stain. But only SCBE and SCEE fractions displayed the presence of some of the compounds with $\mathrm{Rf}$ values similar to that of the standards used as reference. Catechin, rutin and caffeic acid were observed in SCBE while apigenin in SCEE (data not shown).

Catechin is important polyphenolic compound and has shown many beneficial health associated effect in laboratory as well as in clinics due to their antioxidant and free radical scavenging activity along with stimulation of endogenous antioxidants. Catechin and its metabolites have shown potential as neuroprotective, antiapoptotic and anti-inflammatory in clinical disorders [37]. Caffeic acid is reported to have antimetastatic and antitumour activity by suppressing MMP-9 enzyme, an important actor of metastasis and cancer onset [38]. Rutin is important secondary metabolite in many plants and has been reported as hepatoprotective, antioxidant and anti-inflammatory agent [39]. Apigenin is known as a potent antioxidant and antiinflammatory agent [40].

\section{Antioxidant assays}

In vitro antioxidant test are very useful, time saving and economic activity to investigate the antioxidant potential of a plant extract and/or pure compound before commencing the extract/compound to the in vivo model for the antioxidant potential against free radicals. There are so many well established protocols for screening antioxidant potential against different types of free radicals. Here we elaborated anti free radical potential of $S$. cordata against different free radicals.

\section{DPPH radical scavenging activity}

DPPH possesses a proton free radical with property of absorption that decreases on exposure of proton radical scavengers. S. cordata methanol extract and various fractions showed good DPPH radical scavenging activity. DPPH radical scavenging activity was changed notably by various fractions. SCEE showed the lowest $\mathrm{IC}_{50}(135 \pm 1.2$ $\mu \mathrm{g} / \mathrm{ml}$ ) against DPPH free radicals while SCHE showed highest $\mathrm{IC}_{50}$ value $(795 \pm 5.3)$. $\mathrm{IC}_{50}$ values are given in Table 2. Results obtained in this study suggest that DPPH scavenging activity can be enhanced by the partition of crude methanol extract with ethyl acetate organic solvent.

\section{Hydrogen peroxide radical}

Hydrogen peroxide is the reactive oxygen metabolite causing damage to the cell at very low concentration of $10 \mu \mathrm{M}$. It is produced as a result of dismutation of superoxide radicals or directly or indirectly by some enzymes. Free solubility in aqueous, makes it freely movable across biological membranes. Deleterious effects include degradation of heme protein, inactivation of enzymes and oxidation of DNA, lipids, - $\mathrm{SH}$ groups and keto acid [41]. It reacts with $\mathrm{Fe}^{2+}$ and possibly $\mathrm{Cu}^{2+}$ ions to form hydroxyl radicals, which induce many toxic effects [42].

Hydrogen peroxide precursor of toxic hydroxyl radical is non reactive free radical species. Scavenging activity of extract and various fractions was observed to be concentration dependent (Additional file 1: Figure S1). SCEE illustrated the lowest $\mathrm{IC}_{50}(154 \pm 2.3 \mu \mathrm{g} / \mathrm{ml})$ while other fractions showed activity in the order of SCBE $<$ SCME < SCHE $<$ SCAE with $\mathrm{IC}_{50}$ of $223 \pm 2.1,272 \pm 1.8,469 \pm 2.7$ and $622 \pm 3.7 \mu \mathrm{g} / \mathrm{ml}$, respectively (Table 2 ).

\section{Hydroxyl radical scavenging activity}

Hydroxyl is very toxic free radical, causing damage to deoxyribonucleic acids and proteins. In the present experiment, the evidence of $\cdot \mathrm{OH}$ scavenging activity by $S$. cordata extract and fractions were obtained through the deoxyribose system. S. cordata samples scavenged $\bullet \mathrm{OH}$ radicals in a concentration dependent manner and organic solvent fraction type wise. Best hydroxyl radical scavenging activity was shown by SCEE with $\mathrm{IC}_{50}$ value of 189 $\pm 1.5 \mu \mathrm{g} / \mathrm{ml}$ while the highest value range was recorded by SCHE $(578 \pm 4.2 \mu \mathrm{g} / \mathrm{ml})$ as shown in Table 2. The strong antioxidant activity of SCEE can be utilized as a source of natural antioxidant in oxidative stress for minimizing the detrimental effects of hydroxyl radical in the body. 
Table $2 \mathrm{IC}_{50}$ values of different antioxidant assays of extract and various fractions of S. cordata

\begin{tabular}{|c|c|c|c|c|c|c|}
\hline \multirow[t]{2}{*}{ Activity } & \multicolumn{6}{|c|}{$\mathrm{IC}_{50}(\mu \mathrm{g} / \mathrm{ml})$} \\
\hline & SCME & SCHE & SCEE & SCBE & SCAE & Standard $^{\mathrm{a}}$ \\
\hline DPPH scavenging activity & $235 \pm 1.4^{c}$ & $795 \pm 5.3^{\mathrm{a}}$ & $135 \pm 1.2^{\mathrm{e}}$ & $147 \pm 1.4^{d}$ & $275 \pm 3.2^{b}$ & $25 \pm 1.1^{f}$ \\
\hline Hydrogen peroxide scavenging activity & $272 \pm 1.8^{c}$ & $469 \pm 2.7^{b}$ & $154 \pm 2.3^{\mathrm{e}}$ & $223 \pm 2.1^{d}$ & $622 \pm 3.7^{\mathrm{a}}$ & $99 \pm 2.2^{f}$ \\
\hline Hydroxyl radical scavenging activity & $298 \pm 2.1^{c}$ & $578 \pm 4.2^{\mathrm{a}}$ & $189 \pm 1.5^{d}$ & $206 \pm 1.3^{e}$ & $455 \pm 4.1^{\mathrm{b}}$ & $32 \pm 0.9^{f}$ \\
\hline ABTS scavenging activity & $259 \pm 0.9^{a}$ & $260 \pm 2.1^{a}$ & $143 \pm 0.8^{d}$ & $224 \pm 1.4^{c}$ & $236 \pm 2.2^{b}$ & $55 \pm 1.3^{e}$ \\
\hline Anti lipid per oxidation activity & $212 \pm 3.1^{c}$ & $276 \pm 2.6^{b}$ & $119 \pm 1.0^{\mathrm{e}}$ & $153 \pm 1.1^{d}$ & $314 \pm 2.8^{\mathrm{a}}$ & $31 \pm 0.8^{f}$ \\
\hline$\beta$-carotene bleaching activity & $221 \pm 1.7^{c}$ & $647 \pm 3.9^{\mathrm{a}}$ & $153 \pm 1.1^{d}$ & $156 \pm 1.7^{\mathrm{d}}$ & $249 \pm 1.6^{\mathrm{b}}$ & $35 \pm 1.7^{\mathrm{e}}$ \\
\hline Superoxide radical scavenging activity & $139 \pm 2.0^{c}$ & $197 \pm 2.3^{b}$ & $114 \pm 1.3^{d}$ & $136 \pm 2.1^{c}$ & $242 \pm 3.1^{\mathrm{a}}$ & $41 \pm 2.3^{e}$ \\
\hline
\end{tabular}

Values are expressed as mean $\pm \mathrm{SD}(\mathrm{N}=3),{ }^{\mathrm{a}}=$ Ascorbic acid. Means with superscripts with different letters in the rows are significantly $(\mathrm{P}<0.05)$ different from each other. (SCHE); $n$-hexane fraction, (SCEE); ethyl acetate fraction, (SCBE); $n$-butanol fraction, (SCAE), aqueous fraction.

\section{ABTS radical scavenging activity}

ABTS radical scavenging activity of extract and various fractions was evaluated by using 2, 2 azobis-(3ethylbenzothiozoline-6-s $\mu$ lphonic acid). Best ABTS radical scavenging effect was shown by SCEE $\left(\mathrm{IC}_{50}=143 \pm 0\right.$. $8 \mu \mathrm{g} / \mathrm{ml}$ ), higher than the standard used but comparable. $\mathrm{IC}_{50}$ values of SCME versus SCHE and SCBE versus SCAE displayed no significant difference (Table 2). ABTS radical scavenging activity was observed to be dose dependent.

\section{Anti lipid peroxidation potential}

Egg yolk lipids on reaction with ferrous sulphate undergo rapid non enzymatic peroxidation. Lipid peroxides are possible causative agent of inflammation, oxidative stress, metabolic malfunctioning and aging. The $\mathrm{IC}_{50}$ values of lipid peroxidation activity of $S$. cordata extract and various fractions is summarized in Table 2. Maximum anti-lipid peroxidation activity was observed by SCEE and lowest by SCAE with $\mathrm{IC}_{50}$ values of 119 $\pm 1.0 \mu \mathrm{g} / \mathrm{ml}$ and $314 \pm 2.8 \mu \mathrm{g} / \mathrm{ml}$ respectively.

\section{Beta carotene scavenging activity}

Antioxidant potential of $S$. cordata extract and fraction was determined by $\beta$-carotene bleaching method based on the oxidation of linoleic acid. Linoleic acid hydroperoxides react with $\beta$-carotene molecule resulting in the rapid disappearance of color. The presence of antioxidant can obstruct the extent of $\beta$-carotene by acting on linoleate free radicals and other free radicals formed in the system. So the absorbance rapidly decreased in samples without antioxidants whereas in the presence of an antioxidant, they maintained their absorbance and color for a longer period. Among S. cordata samples, SCEE showed promising $\left(\mathrm{IC}_{50}=153 \pm 1.1 \mu \mathrm{g} / \mathrm{ml}\right) \quad \beta$-carotene bleaching antioxidant activity followed by SCBE (156 $\pm 1.7 \mu \mathrm{g} / \mathrm{ml})>\operatorname{SCME}(221 \pm 1.7 \mu \mathrm{g} / \mathrm{ml})>\operatorname{SCAE}(249 \pm 1.6$ $\mu \mathrm{g} / \mathrm{ml})>\operatorname{SCHE}(647 \pm 3.9 \mu \mathrm{g} / \mathrm{ml})$ (Table 2$)$. This activity observed to be concentration dependent.

\section{Superoxide radical scavenging activity}

Oxidation is an important phenomenon of life, but apart from so many crucial processes of life, during normal metabolism of oxygen, various free as well as superoxide's are continuously produced. It is considered a weak oxidant, but gives rise to toxic and powerful oxidant such as hydroxyl radical and singlet oxygen resulting in many diseases [43].

S. cordata showed superoxide radical scavenging activity with best $\mathrm{IC}_{50}$ of $114 \pm 1.3 \mu \mathrm{g} / \mathrm{ml}$ for SCEE, while remaining extract and fractions with $\mathrm{IC}_{50}$ of $136 \pm 2.1$, $139 \pm 2.0, \quad 197 \pm 2.3,242 \pm 3.1 \mu \mathrm{g} / \mathrm{ml}$ for SCBE, SCME, SCHE, SCAE respectively (Table 2).

\section{Reducing power}

Reducing power of the plant was determined by using potassium ferricyanide reduction method. Now it is an established phenomenon that reducing power is linked with antioxidant potential and it correlates with phenolic constituents in several vegetables. In reducing power assay, the oxidation form of iron $\left(\mathrm{Fe}^{+3}\right)$ in ferric chloride is converted to ferrous $\left(\mathrm{Fe}^{+2}\right)$ by antioxidant compounds. Extract and different fractions of $S$. cordata expressed good reducing power activity. SCEE and SCME showed reducing power with the approximate absorbance value $0.647 \pm 0.08$ and $0.583 \pm 0.07$ respectively at maximum dose of $200 \mu \mathrm{g} /$ $\mathrm{ml}$ in comparison to standard gallic acid $(1.13 \pm 0.03)$.

Now it is an established phenomenon that reducing power is linked with antioxidant potential and it correlates with phenolic constituents in several vegetables/ foods. The reducing power of a compound may serve as an important marker of its possible antioxidant activity. However, the activities of antioxidants have been ascribed to various mechanisms such as prevention of chain initiation, decomposition of peroxides, reducing capacity and radical scavenging [44].

\section{Phosphomolybdenum assay}

Phosphomolybdenum assay principal follows the chemistry of conversion of Mo (VI) to Mo (V) by compound/ 
extract having antioxidant property and resulting in formation of green phosphate/Mo (V) compound with maximum absorption at $695 \mathrm{~nm}$. In the present assay all the Sida cordata different samples showed good total antioxidant index in order of SCEE > SCME > SCBE > SCAE > SCHE at a highest dose of $200 \mu \mathrm{g} / \mathrm{ml}$. SCEE value of antioxidant index $(1.129 \pm 0.01)$ is comparable with standard ascorbic acid (1.73 \pm 0.23$)$.

\section{Correlation between $\mathrm{IC}_{50}$ values and phytochemical constituents}

Correlation between $\mathrm{IC}_{50}$ values of various radical scavenging activities with total phenolic and total flavonoids constituents is given in Table 3. All the fractions showed good correlation with total flavonoid contents $\left(R^{2}=0.57-0.92\right)$ and total phenolic contents $\left(R^{2}=0.44-0.97\right)$. Significant correlations $(\mathrm{P}<0.01, \mathrm{P}<0.05)$ of $\mathrm{IC}_{50}$ were observed with total flavonoid contents and total phenolic contents in all antioxidant assays except DPPH scavenging activity and $\beta$-carotene bleaching activity.

\section{In vivo studies}

Besides in vitro antioxidant activity, in vivo study was performed on SCEE, showing best antioxidant potential as well as good flavonoid and phenolic contents among $S$. cordata methanol extract and its various derived fractions during in vitro assays. Flavonoids are considered good hepatoprotective agents [45]. To assess this potential of SCEE fraction, it was applied against $\mathrm{CCl}_{4}$ induced hepatic toxicity. $\mathrm{CCl}_{4}$ is extensively used in animal models to look into chemical toxin induced hepatic damage. It induces cirrhosis, necrosis and fats deposition resulting from formation of trichloromethyl free radicals [46].

For in vivo study, doses of 150 and $300 \mathrm{mg} / \mathrm{kg}$ b.w were selected for hepatoprotection against $\mathrm{CCl}_{4}$-induced toxicity study.

$\mathrm{CCl}_{4}$ was injected on alternate day (thirty days) to induce hepatotoxicity in animal model. $\mathrm{CCl}_{4}$ is recognized to cause liver damage marked in striking augmentation

Table 3 IC $_{50}$ correlation with total flavonoid and total phenolic contents

\begin{tabular}{lcc}
\hline Activity & \multicolumn{2}{c}{ Correlation $\mathbf{R}^{\mathbf{2}}$} \\
\cline { 2 - 3 } & Flavonoids & Phenolics \\
\hline DPPH scavenging activity & 0.57 & 0.46 \\
Hydrogen peroxide scavenging activity & $0.78^{*}$ & $0.86^{*}$ \\
Hydroxyl radical scavenging activity & $0.89^{* *}$ & $0.85^{*}$ \\
ABTS scavenging activity & $0.67^{*}$ & 0.65 \\
Anti lipid per oxidation activity & $0.92^{* *}$ & $0.97^{* *}$ \\
$\beta$ - carotene bleaching scavenging activity & 0.55 & 0.44 \\
Superoxide radical scavenging activity & $0.73^{*}$ & $0.82^{*}$ \\
\hline
\end{tabular}

Values are expressed as mean $\pm \mathrm{SD}(\mathrm{N}=3)$. Values within the same column with different superscripts letter are significantly different. ${ }^{*}=\mathrm{P}<0.05 ;{ }^{* *}=\mathrm{P}<0.01$. in serum profile of LDH, bilirubin, $\gamma$-GT, ALP and aminotransferase enzymes (ALT and AST), especially ALT, which is considered the specific and primary indicator of hepatic injury. Accordingly, our results also demonstrated a significant increase in the profile of ALT, AST and LDH after $\mathrm{CCl}_{4}$ treatment (Table 4), hence confirming the liver damage at the cellular level in $\mathrm{CCl}_{4}$-treated rats. SCEE treatment markedly lowered the level of marker enzymes near to that of control groups.

In the present experiments after the treatment of $\mathrm{CCl}_{4}$ the levels of the serum markers got elevated, suggesting liver injuries in $\mathrm{CCl}_{4}$ treated groups. A similar profile was also observed by Khan and colleagues [47] in rat after treatment with $\mathrm{CCl}_{4}$.

The effect of SCEE on different antioxidant enzymes (CAT, POD, SOD, GST, GSH- $\mathrm{P}_{\mathrm{X}}$ and GSR) profile is given in Table 5. Administration of $\mathrm{CCl}_{4}$ markedly $(\mathrm{P}<0.05)$ reduced the level of antioxidant enzymes in the $\mathrm{CCl}_{4}$ treated group when compared to that of control group, but its profile was obviously reversed by SCEE dose dependently.

Antioxidant enzymes represent protective system against tissue damage by oxidation. SOD transformed $\mathrm{O}_{2}$ into $\mathrm{H}_{2} \mathrm{O}_{2}$. GSH-Px and CAT metabolize $\mathrm{H}_{2} \mathrm{O}_{2}$ to non damaging products. GSH antioxidant network play elementary role in cellular protection against free radical species. This system comprises GSH and a group of functionally connected enzymes of which GSR is accountable for GSH regeneration while GSH-Px and GST function jointly with GSH for conversion of $\mathrm{H}_{2} \mathrm{O}_{2}$ to hydroperoxides [48].

GSH-Px that play a key role in the free radical neutralization was significantly lowered after $\mathrm{CCl}_{4}$ treatments but restored in rats treated with SCEE. These findings suggest that $\mathrm{CCl}_{4}$ probably through its converted forms in the liver after administration, hinder the activity of GSH-Px. Similarly, after $\mathrm{CCl}_{4}$ treatment levels of CAT, POD, and SOD were also decreased and normalized with the treatment of SCEE.

P450-2E1 convert $\mathrm{CCl}_{4}$ to $\mathrm{CCl}_{3}$ in the animal tissue which induce toxicity in tissues but in the same time GSH detoxifying pathway also activated, resulting in the conjugation of toxic metabolite $\mathrm{CCl}_{3}$ [17]. Recknagel et al. [49] in their study of $\mathrm{CCl}_{4}$ toxicity induction in liver showed that GSH is a key player in removing toxic metabolite of $\mathrm{CCl}_{4}$, and $\mathrm{CCl}_{4}$ toxicity starting to appear when GSH profile is exhausted.

The effect of SCEE on protein, TBARS, and GSH profile is displayed in Table 6. Protein and GSH levels were significantly reduced due to the toxicity of $\mathrm{CCl}_{4}$. SCEE treatment dose dependently protected its alteration and showed profile near to control group. TBARS levels were augmented significantly and reversed by SCEE treatment.

SCEE administration also prevented the $\mathrm{CCl}_{4}$ induced increase in liver TBARS levels, suggesting that SCEE obstruct lipid peroxidation and its promulgation reactions 
Table 4 Effect of SCEE treatment on different liver markers

\begin{tabular}{|c|c|c|c|c|c|c|}
\hline Group & LDH (U/L) & Billirubin (mg/ml) & ALT (U/L) & AST (U/L) & $\operatorname{ALP}(U / L)$ & $\mathrm{V}-\mathrm{GT}(\mathrm{U} / \mathrm{L})$ \\
\hline Control & $1847 \pm 21.2^{\mathrm{e}}$ & $0.33 \pm 0.1^{\mathrm{b}}$ & $22.67 \pm 1.5^{\mathrm{b}}$ & $38.7 \pm 3.5^{d}$ & $56.0 \pm 1.0^{c d}$ & $0.937 \pm 0.0^{\text {de }}$ \\
\hline Oil+DMSO & $1964 \pm 30.2^{c d}$ & $0.33 \pm 0.1^{b}$ & $21 \pm 1.00^{b c}$ & $40.3 \pm 1.5^{\mathrm{cd}}$ & $54.0 \pm 1.0^{d}$ & $0.863 \pm 0.0^{\mathrm{e}}$ \\
\hline $\mathrm{CCl}_{4}(1 \mathrm{ml} / \mathrm{kg})$ & $3268 \pm 55.7^{\mathrm{a}}$ & $0.90 \pm 1.0^{\mathrm{a}}$ & $43.3 \pm 1.5^{\mathrm{a}}$ & $70.0 \pm 3.0^{\mathrm{a}}$ & $91.3 \pm 2.5^{\mathrm{a}}$ & $2.58 \pm 0.21^{a}$ \\
\hline Silymarin $(200 \mathrm{mg} / \mathrm{kg})+\mathrm{CCl}_{4}$ & $1753 \pm 15.3^{f}$ & $0.37 \pm 0.1^{b}$ & $18.0 \pm 1.0^{\mathrm{a}}$ & $44.7 \pm 2.5^{\mathrm{cd}}$ & $60.3 \pm 2.5^{c}$ & $1.16 \pm 0.10^{\mathrm{cd}}$ \\
\hline SCEE $(150 \mathrm{mg} / \mathrm{kg})+\mathrm{CCl}_{4}$ & $2207 \pm 21.4^{b}$ & $0.43 \pm 0.1^{b}$ & $20.0 \pm 1.0^{b c}$ & $56.3 \pm 3.1^{b}$ & $71.3 \pm 1.5^{b}$ & $1.77 \pm 0.20^{b}$ \\
\hline SCEE $(300 \mathrm{mg} / \mathrm{kg})+\mathrm{CCl}_{4}$ & $2054 \pm 48.0^{c}$ & $0.43 \pm 0.1^{b}$ & $20.5 \pm 0.5^{b c}$ & $47.0 \pm 2.6^{c}$ & $69.0 \pm 1.0^{b}$ & $1.35 \pm 0.17^{c}$ \\
\hline SCEE $(300 \mathrm{mg} / \mathrm{kg})$ & $1902 \pm 20.4^{d}$ & $0.33 \pm 0.1^{b}$ & $22.0 \pm 1.0^{b}$ & $40.7 \pm 2.5^{c d}$ & $58.7 \pm 1.5^{\mathrm{cd}}$ & $1.04 \pm 0.10^{\text {de }}$ \\
\hline
\end{tabular}

Values are expressed as mean $\pm \mathrm{SD}(\mathrm{N}=3)$. Values within the same column with different superscripts letters are significantly $(\mathrm{P}<0.05)$ different. (SCHE); $n$-hexane fraction, (SCEE); ethyl acetate fraction, (SCBE); $n$-butanol fraction, (SCAE), aqueous fraction.

as expressed by in vitro assays. $\mathrm{CCl}_{4}$ caused noticeable toxicity by increasing the hepatic lipid peroxides, as marked by higher levels of hepatic TBARS. It is well known that $\mathrm{CCl}_{4}$ induce liver toxicity is attributed to the reductive dehalogenation of $\mathrm{CCl}_{4}$, catalyzed by CYP450 in the hepatic endoplasmic reticulum, leading to the generation of trichloromethyl peroxy radicals $\left(\cdot \mathrm{CCl}_{3}\right)$, which is reported to be an unstable complex and belongs to highly reactive species [50]. This free radical reacts with lipids of membrane, leading to per oxidation, and may also cause cell damage by covalently binding to proteins and lipids resulting in harmful processes. SCEE may give cell protection by hindering $\mathrm{CCl}_{4}$-mediated lipid peroxidation, hence blocking the generation of free radical derivatives [49]. If the elevated TBARS levels are taken into consideration, $\mathrm{CCl}_{4}$ exposure increased lipid peroxidation, it also lowered intracellular GSH profile, demonstrating that GSH depletion might arise from the detoxification of $\mathrm{CCl}_{4}$ by $\mathrm{GSH}$ conjugation. Therefore, these combined results strongly suggest that SCEE also acts as an antioxidant in animal model. This effect could be characteristic of the antioxidant activity of the $S$. cordata SCEE fraction used, which markedly diminished the oxidative hazard and paved to reinstatement of normal physiological features. In addition, the antioxidant enzymes in rats co-treated with SCEE have activities similar to those of controls. These effects can be attributed here to SCEE by playing a role during the early stages in $\mathrm{CCl}_{4}$ induced hepatic damage, diminishing lipid peroxidation consequently and improving cellular antioxidant position, thereby obstructing AST, ALT and LDH outflow from the liver.

Liver tissue slides were stained with hemotoxylin and eosin (Figure 2). $\mathrm{CCl}_{4}$ administration as depicted in Figure 2c shows central vein dilation, inflammatory cells infiltration, cellular hypertrophy, necrosis and degeneration of lobular architecture. Similar alterations were reported by Khan et al. [51] in their study in rat after $\mathrm{CCl}_{4}$ treatment. SCEE administration resulted in minimizing of such morphological alterations dose dependently and clear difference can be observed in histoarchitecture to that of $\mathrm{CCl}_{4}$ treated. Animals treated with SCEE alone did not revealed any alteration in morphology of the liver. However, only macrosteatosis in hepatocytes was reported by Mistry et al. [14] with an ethanol extract of $S$. cordata leaves. This difference in alteration of histoarchitecture might be due to the different animal breed and/or intensity and duration of the $\mathrm{CCl}_{4}$ treatment.

The main flavonoid present in the SCEE, identified by TLC fingerprinting was apigenin. Apigenin is known to have a role in the amplification of profile of antioxidant enzymes i.e. superoxide dismutase and erythrocyte glutathione reductase [52]. It induces reduction of plasma profile of low density lipoprotein, inhibition of platelet aggregation and reduction of cell proliferation [53].

Table 5 Effects of SCEE treatment on antioxidant enzymes profile of liver

\begin{tabular}{|c|c|c|c|c|c|c|}
\hline Group & $\begin{array}{l}\text { CAT } \\
\text { (U/min) }\end{array}$ & $\begin{array}{l}\text { POD } \\
\text { (U/min) }\end{array}$ & $\begin{array}{c}\text { SOD } \\
\text { (U/mg protein) }\end{array}$ & $\begin{array}{c}\text { GST } \\
\text { (nM/min/mg protein) }\end{array}$ & $\begin{array}{c}\text { GSH-Px } \\
\text { (nM/min/mg protein) }\end{array}$ & $\begin{array}{c}\text { GSR } \\
\text { (nM/min/mg protein) }\end{array}$ \\
\hline Control & $6.1 \pm 0.2^{\mathrm{ab}}$ & $10.1 \pm 0.2^{\mathrm{a}}$ & $4.1 \pm 0.2^{\mathrm{a}}$ & $129 \pm 9.5^{\mathrm{a}}$ & $81.1 \pm 4.8^{\mathrm{a}}$ & $131.3 \pm 8.5^{\mathrm{ab}}$ \\
\hline Oil+DMSO & $5.7 \pm 0.2^{\mathrm{bc}}$ & $9.9 \pm 0.2^{\mathrm{a}}$ & $3.9 \pm 0.1^{\mathrm{a}}$ & $113 \pm 6.0^{b c}$ & $73.7 \pm 8.0^{\mathrm{ab}}$ & $121.3 \pm 8.5^{\mathrm{ab}}$ \\
\hline $\mathrm{CCl}_{4}(1 \mathrm{ml} / \mathrm{kg})$ & $1.8 \pm 0.1^{\mathrm{e}}$ & $4.3 \pm 0.2^{b}$ & $1.2 \pm 0.2^{d}$ & $56 \pm 8.0^{e}$ & $47.0 \pm 9.2^{c}$ & $65.7 \pm 6.1^{d}$ \\
\hline Silymarin $(200 \mathrm{mg} / \mathrm{kg})+\mathrm{CCl}_{4}$ & $5.4 \pm 0.1^{c}$ & $8.4 \pm 0.3^{b}$ & $3.2 \pm 0.1^{b}$ & $107 \pm 8.0^{\mathrm{bc}}$ & $73.3 \pm 5.5^{\mathrm{ab}}$ & $111 \pm 6.0^{\mathrm{bc}}$ \\
\hline SCEE $(150 \mathrm{mg} / \mathrm{kg})+\mathrm{CCl}_{4}$ & $3.9 \pm 0.2^{d}$ & $6.6 \pm 0.4^{c}$ & $2.3 \pm 0.2^{c}$ & $82.7 \pm 5.5^{d}$ & $60.3 \pm 3.1^{b c}$ & $94.3 \pm 6.1^{c}$ \\
\hline SCEE $(300 \mathrm{mg} / \mathrm{kg})+\mathrm{CCl}_{4}$ & $4.4 \pm 0.3^{d}$ & $7.3 \pm 0.5^{c}$ & $2.6 \pm 0.2_{c}$ & $101 \pm 6.0^{c d}$ & $65.7 \pm 2.9^{\mathrm{ab}}$ & $111 \pm 5.3^{\mathrm{bc}}$ \\
\hline SCEE (300 mg/kg) & $6.3 \pm 0.2^{\mathrm{a}}$ & $10.2 \pm 0.3^{\mathrm{a}}$ & $4.1 \pm 0.1^{\mathrm{a}}$ & $123 \pm 9.7^{\mathrm{ab}}$ & $71.7 \pm 3.5^{\mathrm{ab}}$ & $135.7 \pm 11.4^{\mathrm{a}}$ \\
\hline
\end{tabular}

Values are expressed as mean $\pm \mathrm{SD}(\mathrm{N}=3)$. Values within the same column with different superscripts letters are significantly $(\mathrm{P}<0.05)$ different. (SCHE); $n$-hexane fraction, (SCEE); ethyl acetate fraction, (SCBE); $n$-butanol fraction, (SCAE), aqueous fraction. 
Table 6 Effects of SCEE administration on protein, TBARS and GSH profile of liver

\begin{tabular}{llll}
\hline Group & $\begin{array}{l}\text { Protein } \\
(\boldsymbol{\mu g} / \mathbf{m g} \text { tissue) }\end{array}$ & $\begin{array}{l}\text { TBARS }(\mathbf{n M} / \mathbf{m i n} / \\
\mathbf{m g} \text { protein) }\end{array}$ & $\begin{array}{l}\text { GSH } \\
(\boldsymbol{\mu M} / \mathbf{g} \text { tissue })\end{array}$ \\
\hline Control & $3.1 \pm 0.1^{\mathrm{a}}$ & $1.3 \pm 0.2^{\mathrm{d}}$ & $29.3 \pm 2.5^{\mathrm{a}}$ \\
Oil+DMSO & $2.6 \pm 0.2^{\mathrm{b}}$ & $1.4 \pm 0.2^{\mathrm{d}}$ & $25.7 \pm 2.1^{\mathrm{a}}$ \\
$\mathrm{CCl}_{4}(1 \mathrm{ml} / \mathrm{kg})$ & $1.3 \pm 0.2^{\mathrm{d}}$ & $3.7 \pm 0.4^{\mathrm{a}}$ & $11.3 \pm 2.5^{\mathrm{c}}$ \\
Silymarin $(200 \mathrm{mg} / \mathrm{kg})+\mathrm{CCl}_{4}$ & $2.8 \pm 0.2^{\mathrm{ab}}$ & $1.8 \pm 0.2^{\mathrm{cd}}$ & $27.3 \pm 3.5^{\mathrm{a}}$ \\
SCEE $(150 \mathrm{mg} / \mathrm{kg})+C \mathrm{Cl}_{4}$ & $1.5 \pm 0.1^{\mathrm{cd}}$ & $2.7 \pm 0.1^{\mathrm{b}}$ & $17.7 \pm 3.1^{\mathrm{bc}}$ \\
SCEE $(300 \mathrm{mg} / \mathrm{kg})+C C l_{4}$ & $1.8 \pm 0.1^{\mathrm{c}}$ & $2.3 \pm 0.2^{\mathrm{bc}}$ & $24.0 \pm 2.7^{\mathrm{ab}}$ \\
SCEE $(300 \mathrm{mg} / \mathrm{kg})$ & $2.8 \pm 0.1^{\mathrm{ab}}$ & $1.6 \pm 0.2^{\mathrm{cd}}$ & $31.0 \pm 2.7^{\mathrm{a}}$ \\
\hline
\end{tabular}

Values are expressed as mean $\pm \mathrm{SD}(\mathrm{N}=3)$. Values within the same column with different superscripts letters are significantly $(\mathrm{P}<0.05)$ different. (SCHE); $n$-hexane fraction, (SCEE); ethyl acetate fraction, (SCBE); $n$-butanol fraction, (SCAE), aqueous fraction.
Jeyabal et al. [54] have shown that apigenin give protection to liver in term of oxidative stress and DNA damage against $\mathrm{N}$-nitroso-diethylamine induced and phenobarbitol promoted liver carcinogenesis in rats when fed at a dose of $25 \mathrm{mg} / \mathrm{kg}$ body weight. We suppose here that apigenin alone or combination with other unknown components may have a role in the reduction of hepatotoxicity induced by $\mathrm{CCl}_{4}$ in rat model. Based on the experimental results in the present study SCEE may play a key role in therapeutics by free radical capturing and activation of antioxidant enzymes may lead to the protection of the liver against $\mathrm{CCl}_{4}$ induced injury. But complete study is required to verify the mechanism of protection against $\mathrm{CCl}_{4}$ by SCEE at the molecular level.
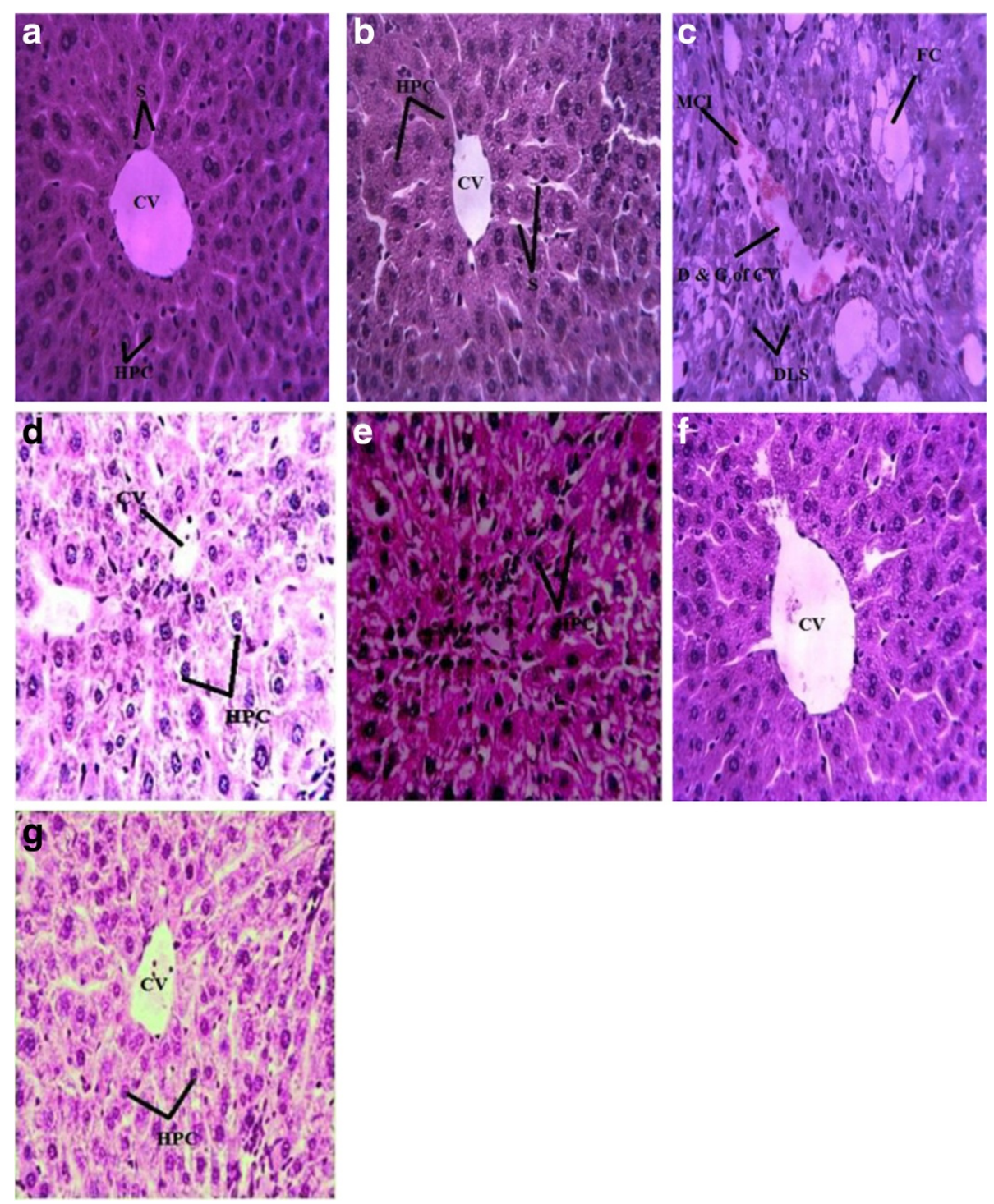

Figure $\mathbf{2}$ Rat liver microscopic photograph (H \& E stain). 2a; Represents normal liver section, 2 b; Vehicle control, $\mathbf{2} \mathbf{c} ; \mathrm{CCl}_{4}$ treated control, $\mathbf{2 d}$ $\mathrm{CCl}_{4}+$ silymerin treated, $\mathbf{2 e} ; \mathrm{CCl}_{4}+\mathrm{SCEE} 150 \mathrm{mg} / \mathrm{kg}$ treated, $\mathbf{2 f} ; \mathrm{CCl}_{4}+\mathrm{SCEE} 300 \mathrm{mg} / \mathrm{kg}$ treated $\mathbf{2 g}$; only SCEE $300 \mathrm{mg} / \mathrm{kg}$ treated. CV (Central vein), S (Sinusoids) and HPC (Hepatocytes). DLS (Degeneration of lobular shape), FC (Fatty change), and D\& C (Dilation and congestion of central vein). 


\section{Conclusion}

Results obtained in the present study shows that SCEE is an active herbal protective drug against hepatotoxicity, but complete investigation is required to isolate the hepatoprotective compound in pure form for drug development on a large scale.

\section{Additional file}

Additional file 1: Figure S1. Antioxidant activity of S. cordata methanol extract and its various derived fractions at different concentrations. (a) DPPH radical scavenging activity (b) Hydrogen peroxide scavenging activity (c) Hydroxyl radical scavenging activity (d) ABTS radical scavenging activity (e) Anti lipid peroxidation activity (f) Beta carotene activity (g) Superoxide radical scavenging activity (h) Reducing power potential (i) Total antioxidant potential.

\section{Competing interest}

The authors declare that they have no competing interests.

\section{Authors' contributions}

NAS made significant contributions to conception, acquisition of data, analysis, drafting of the manuscript. MRK has made substantial contribution to and design, interpretation of data, drafting and revising the manuscript for intellectual content. BA, FN, UR and RAK (Khan RA 0000-0003-0453-2090) participated in the design and collection of data and analysis. All authors read and approved the final manuscript.

\section{Acknowledgment}

Authors acknowledge Higher Education Commission (HEC), Pakistan for supporting this study vide indigenous scholarship for PhD, PIN number BM4189.

\section{Author details}

${ }^{1}$ Department of Biochemistry, Faculty of Biological Sciences, Quaid-i-Azam University, Islamabad 45320, Pakistan. ²Deparment of Biotechnology, Faculty of Biological Sciences, University of Science and Technology Bannu, Khyber Pakhtunkhwa, Pakistan

\section{Received: 6 March 2013 Accepted: 10 October 2013}

Published: 22 October 2013

\section{References}

1. Slater TF: Free radical mechanisms in tissue injury. Biochem J 1984, 222:1-15.

2. Vani T, Rajini M, Sarkar S, Shishoo CJ: Antioxidant properties of the ayurvedic formulation-Triphala and its constituents. Pharmaceu Biol 1997, 35:313-317.

3. Jadhav HR, Bhutani KK: Antioxidant properties of Indian medicinal plants. Phytother Res 2002, 16:771-773.

4. Aragon SM, Basabe B, Benedi JM, Villar AM: Antioxidant activity of Vaccinium myrtillus L. Phytother Res 1998, 12:104-106.

5. Ing-Chien C, Hui-Chi C, Hui-Wen Y, Gan-Lin C: Evaluation of total antioxidant activity of several popular vegetables and Chinese herbs: A fast approach with ABTS/H2O/HRP system in microplates. J Food Drug Anal 2004, 12:29-33.

6. Ohira S, Hasegawa T, Hayasahi Kl, Hoshino T, Takaoka D, Nozaki H: Sesquiterpenoids from Cyperus rotundus. Phytochemistry 1998, 47:577-579.

7. Mekem SM, Konig WA: Study of essiontial oil of Cyperus rotundus. Phytochemistry 2001, 58:799-801.

8. Lutterodt GD: Oxytocic effect of an extract from Sida. J Ethnopharmacol 1988, 23:27-37.

9. Dhanvantari: Dravyaguna. In Materia Medica of Ayurveda. 5th edition. Edited by Dash B. New Delhi, India: Jain Publishers; 1991:201-202.

10. Shinwari I, Khan MA: Folk use of medicinal herbs of Margalla Hills National Park, Islamabad. J Ethnopharmacol 2000, 69:45-56.

11. Lutterodt GD: Response of smooth muscle preparation to muscarinic principle. J Ethnopharmacol 1988, 23:12-22.
12. Thamarai N: Agasthiar Pannendayiram Ennum Perunool Kaviyam. 2nd edition. Chennai: India; 1995:322.

13. Gnanasekaran D, Umamaheswara RC, Jaiprakash B, Narayanan N, Hannah E, Ravi KY: In vitro hepatoprotective activity of a selected Siddha medicinal plant S. cordata using chang liver cells. Am j Pharm Res 2012, 2:466-473.

14. Mistry S, Dutt KR, Jena J: Protective effect of $S$. cordata leaf extract against $\mathrm{CCl}_{4}$ induced acute liver toxicity in rats. Asian Pac J Trop Med 2013, 6:280-284.

15. Kim DO, Jeong SW, Lee CY: Antioxidant capacity of phenolic phytochemicals from various cultivars of plums. Food Chem 2003, 81:321-326.

16. Park YS, Jung ST, Kang SG, Heo BK, Arancibia AP, Toledo F, Drzewiecki J, Namiesnik J, Gorinstein S: Antioxidants and proteins in ethylene-treated kiwifruits. Food Chem 2008, 107:640-648.

17. Ahmad I, Beg AZ: Antimicrobial and phytochemical studies on 45 Indian medicinal plants against multi-drug resistant human pathogens. J Ethnopharmacol 2001, 74:113-123.

18. Sirajuddin M, Ali S, Shah NA, Khan MR, Tahir MN: Synthesis, characterization, biological screenings and interaction with calf thymus DNA of a novel Azomethine 3-((3, 5-dimethylphenylimino) methyl) benzene-1, 2-diol. Spectro Acta Part A: Mol Biomol Spectro 2012, 94:134-142.

19. Bokhari J, Khan MR, Shabbir M, Rashid U, Jan S, Zai JA: Evaluation of diverse antioxidant activities of Galium aparine. Spectro Acta Part A: Mol Biomol Spectro 2013, 102:24-29.

20. Halliwell B, John G, Okezie I: The deoxyribose method: a simple "testtube" assay for determination of rate constants for reactions of hydroxyl radicals. Anal biochem 1987, 165:215-219.

21. Re R, Pellegrini N, Proteggente A, Pannala A, Yang M, Rice-Evans C: Antioxidant activity applying an improved ABTS radical cation decolorisation assay. Free Rad Biol Med. 1999, 26:1231-1237.

22. Dorman HJD, Kosar M, Kahlos K, Holm Y, Hiltunen R: Antioxidant properties and composition of aqueous extracts from Mentha species, hybrids, varieties, and cultivars. J Agric Food Chem 2003, 51:4563-4569.

23. Elzaawely AA, Xuan TD, Koyama H, Tawata S: Antioxidant activity and contents of essential oil and phenolic compounds in flowers and seeds of A. zerumbet (Pers.) B.L. Burtt. \& R.M. Sm. Food Chem 2007, 104:1648-1653.

24. Nishikimi M, Rao NA, Yagi K: The occurence of superoxide anion in the reaction of reduced phenazine methosulfate and molecular oxygen. Biochem Biophys Res Commun 1972, 46:849-854.

25. Oyaizu M: Studies on products of the browning reaction: Antioxidative activities of browning reaction products prepared from glucosamine. Jap J Nut [Eiyogaku Zasshi] 1986, 44:307-315.

26. Umamaheswari $M$, Chatterjee $\mathrm{T}$ : In vitro antioxidant activities of the fractions of Coccinia grandis L. leaf extract. African J Trad Com Alt Med 2008, 5:61-73

27. Lagarto PA, Silva YR, Guerra SI, Iglesias BL: Comparative study of the assay of Artemia salina $L$. and the estimate of the medium lethal dose $\left(\mathrm{LD}_{50}\right.$ value) in mice, to determine oral acute toxicity of plant extracts. Phytomedicine 2001, 8:395-400.

28. Patrick-Iwuanyanwu KC, Onyeike EN, Wegwu MO: Hepatoprotective effects of methanolic extract and fractions of African mistletoe Tapinanthus bangwensis (Engl. \& K. Krause) from Nigeria. EXCLI Journal 2010, 9:187-194.

29. Lowry OH, Rosenberg NJ, Farr AL, Randall RJ: Protein measurement with Folin Phenol reagent. J Biol Chem 1974, 193:265-275.

30. Chance B, Maehly AC: Assay of catalase and peroxidases. Method Enzymol 1955, 11:764-775.

31. Kakkar P, Das B, Viswanathan PN: A modified spectrophotometric assay of superoxide dimutase. Indian J Biochem Biophys 1984, 21:130-132.

32. Habig WH, Pabst MJ, Jakoby WB: Glutathione-S-transferases: the first enzymatic step in mercapturic acid formation. J Biol Chem 1974 249:7130-7139.

33. Carlberg I, Mannervik EB: Glutathione level in rat brain. J Biol Chem 1975, 250:4475-4480.

34. Mohandas J, Marshal JJ, Duggin GG, Horvath JS, Tiller DJ: Differential distribution of glutathione and glutathione-related enzymes in rabbit kidney. Possible implications in analgesic nephropathy. Biochem Pharmacol 1984, 33:1801-1807.

35. Jollow DJ, Mitchell JR, Zampaglione N, Gillete JR: Bromobenzene induced liver necrosis. Protective role of glutathione and evidence for 3,4-bromobenzene oxide as a hepatotoxic metabolite. Pharmacology 1974, 11:151-169.

36. Iqbal M, Sharma SD, Zadeh HR, Hasan N, Abdulla M, Athar M: Glutathione metabolizing enzymes and oxidative stress in ferric nitrilotriacetate (Fe-NTA) mediated hepatic injury. Redox Rep 1996, 2:385-391. 
37. Sutherland $B A$, Rahman $R$, Appleton I: Mechanisms of action of green tea catechins, with a focus on ischemia-induced neurodegeneration. J Nut Biochem 2006, 17:291-306.

38. Chung TW, Moon SK, Chang YC, Ko JH, Lee YC, Cho G, Kim SH, Kim JG, Kim CH Novel and therapeutic effect of caffeic acid and caffeic acid phenyl ester on hepatocarcinoma cells: complete regression of hepatoma growth and metastasis by dual mechanism. The FASEB $J$ 2004, 18:1670-1681.

39. Kubola J, Siriamornpun S: Phytochemicals and antioxidant activity of different fruit fractions (peel, pulp, aril and seed) of Thai gac (Momordica cochinchinensis Spreng). Food Chem 2011, 127:1138-1145.

40. Kim HY, Kim OH, Sung MK: Effects of phenol-depleted and phenol-rich diets on blood markers of oxidative stress, and urinary excretion of quercetin and kaempferol in healthy volunteers. J Am Coll Nutr 2003, 22:217-223

41. Kohen R, Nyska A: Invited review: Oxidation of biological systems: oxidative stress phenomena, antioxidants, redox reactions, and methods for their quantification. Toxicol Path 2002, 30:620-650.

42. Taylor BS, Kim YM, Wang QI, Shapiro RA, Billiar TR, Geller DA: Nitric oxide down-regulates hepatocyte-inducible nitric oxide synthase gene expression. Arch Surg 1997, 132:1177.

43. Saeed N, Khan MR, Shabbir M: Antioxidant activity, total phenolic and total flavonoid contents of whole plant extracts Torilis leptophylla L. BMC Complement Altern Med 2012, 12:221.

44. Yildirim A, Mavi A, Oktay M, Kara AA, Algur ÖF, Bilaloglu V: Comparison of antioxidant and antimicrobial activities of Tilia (Tilia argentea Desf ex DC), sage (Salvia triloba L.), and Black tea (Camellia sinensis) extracts. J Agri F Chem 2000, 48:5030-5034

45. Khan MR, Zehra H: Amelioration of CCl4-induced nephrotoxicity by Oxalis corniculata in rat. Exper Toxicol Pathol 2013, 65:327-334.

46. Sahreen S, Khan MR, Khan RA: Ameliorating effect of various fractions of Rumex hastatus roots against hepato- and testicular toxicity caused by CCI4. Oxid Med Cell Longev 2013, 2013:325406.

47. Khan RA, Khan MR, Sahreen S, Shah NA: Hepatoprotective activity of Sonchus asper against carbon tetrachloride-induced injuries in male rats: a randomized controlled trial. BMC Complement Alter Med 2012, 12:90.

48. Mak DH, Ip SP, Li PC, Poon MK, Ko KM: Alterations in tissue glutathione antioxidant system in Streptozotocin-induced diabetic rats. Mol Cell Biochem 1996, 162:153-158

49. Recknagel RO, Glende EA, Britton RS: Free radical damage and lipid peroxidation. In Hepatotoxicology. Edited by Meeks RG, Harrison SD, Bull RJ. Boca Raton, FL: CRC Press; 1991:401-436.

50. Williams AT, Burk RF: Carbon tetrachloride hepatotoxicity: an example of free radical-mediated injury. Semin Liver Dis 1990, 10:279-284.

51. Sahreen S, Khan MR, Khan RA: Hepatoprotective effects of methanol extract of Carissa opaca leaves on $\mathrm{CCl}_{4}$-induced damage in rat. BMC Complement Alter Med 2011, 11:48.

52. Nielsen SE, Young JF, Daneshvar B, Lauridsen ST, Knuthsen P, Sandstrom B, Dragsted LO: Effect of parsley (Petroselinum crispum) intake on urinary apigenin excretion, blood antioxidant enzymes and biomarkers for oxidative stress in human subjects. Br J Nutr 1999, 81:447-455.

53. O'Prey J, Brown J, Fleming J, Harrison PR: Effects of dietary flavonoids on major signal transduction pathways in human epithelial cells. Biochem Pharmacol 2003, 66:2075-2088.

54. Jeyabal PV, Syed MB, Venkataraman M, Sambandham JK, Sakthisekaran D: Apigenin inhibits oxidative stress-induced macromolecular damage in $\mathrm{N}$-nitrosodiethylamine (NDEA)-induced hepatocellular carcinogenesis in Wistar albino rats. Mol Carcinog 2005, 44:11-20.

doi:10.1186/1472-6882-13-276

Cite this article as: Shah et al: Investigation on flavonoid composition and anti free radical potential of Sida cordata. BMC Complementary and Alternative Medicine 2013 13:276.

\section{Submit your next manuscript to BioMed Central and take full advantage of:}

- Convenient online submission

- Thorough peer review

- No space constraints or color figure charges

- Immediate publication on acceptance

- Inclusion in PubMed, CAS, Scopus and Google Scholar

- Research which is freely available for redistribution

Submit your manuscript at www.biomedcentral.com/submit
C Biomed Central 